\title{
Co-production in Business Counselling in Microfinance Setting: A conceptual approach
}

Ruwan Abeysekera

Postgraduate Researcher

Business School, Executive Business Centre

Bournemouth University, 89, Holdenhurst Road, Bournemouth. Dorset

BH8 8EB,

UK

Email: rabeysekera@bournemouth.ac.uk

Professor Dean Patton

Professor in Entrepreneurship/Deputy Dean (Enterprise)

Business School, Executive Business Centre,

Bournemouth University, 89, Holdenhurst Road, Bournemouth. Dorset BH8 8EB,

UK

Professor Andrew Mullineux

Deputy Dean (Research)

Business School, Executive Business Centre,

Bournemouth University, 89, Holdenhurst Road, Bournemouth. Dorset

BH8 8EB,

UK 


\begin{abstract}
Recent developments in service literature highlight the importance of co-production between the firm and the client in order to create value. This paper presents a model of co-production within the context of microfinance provision and investigates the dyadic relationship between Counsellors from Microfinance Institutions (MFIs) and the Owner Managers of Micro and Small Enterprises (MSEs). The paper develops a conceptual model that identifies the factors that facilitate co-production between Counsellors and Owner Managers. It also identifies coproduction outcomes relating to MSEs and MFIs concerned. The model offers researchers a framework for empirical studies in the microfinance setting. Furthermore, microfinance policy makers can use this model to formulate strategies that offer many benefits to both MFIs and Owner Managers.
\end{abstract}




\title{
Co-production in business counselling in Microfinance Setting: A conceptual approach
}

\begin{abstract}
Recent developments in service literature highlight the importance of co-production between the firm and the client in order to create value. This paper presents a model of co-production within the context of microfinance provision and investigates the dyadic relationship between Counsellors from Microfinance Institutions (MFIs) and the Owner Managers of Micro and Small Enterprises (MSEs). The paper develops a conceptual model that identifies the factors that facilitate co-production between Counsellors and Owner Managers. It also identifies coproduction outcomes relating to MSEs and MFIs concerned. The model offers researchers a framework for empirical studies in the microfinance setting. Furthermore, microfinance policy makers can use this model to formulate strategies that offer many benefits to both MFIs and Owner Managers.
\end{abstract}

\section{Introduction}

Micro and Small Enterprises (MSEs) play a significant role in developing countries by contributing to the economic growth and generating employments (Mead and Lieadholm, 1998; Tybout, 2000). Despite the importance of micro enterprises to the economies they are constrained by low capital, traditional technology, entrepreneurial skills and little linkages to other sectors (SAARC, 2000; Rogerson, 2001). Microfinance Institutions provide micro credit and Business Development Services (BDS) entrepreneurs to circumvent these constraints (SARRC, 2000; Merten and Paul, 2007; LMPA, 2012). Micro credit is the issuance of small unsecured loans to entrepreneurs whereas BDS are non financial services such as management training, vocational training skills, marketing assistance, technology access etc. provided to entrepreneurs by MFIs (Merten and Paul, 2007; Khavul, 2010).

MFIs have achieved some success in empowering entrepreneurs through the provision of credit (Littlefield et al., 2003). However, it is evident that credit (capital) alone is not 
sufficient to achieve the desired development effect of promoting entrepreneurs (Rogaly, 1996; Hulme and Mosley, 1996; Johnson and Rogaly, 1997; Mosley and Hulme, 1998; Gulli and Berger, 1999; Wright, 1999). Entrepreneurs not only need credit (capital) but also certain other non- financial assistance often referred to as BDS (i.e. entrepreneurial competencies, resources) to become successful entrepreneurs (Chirsman and Mcmullan, 2004; Phillip, 2004; Merten and Paul, 2007). Thus policy makers and practitioners of Microfinance try to promote BDS to MFIs. The counsellors attached to MFIs play a vital role in delivering BDS to clients (entrepreneurs). We believe that dyadic relationship between the entrepreneur and the counsellor of MFI matter a lot in delivering BDS and achieving goals of BDS. Thus we use theory of co-production which might help to have a deeper understanding on dyadic relationship between the counsellor and the entrepreneur. The deeper understanding on coproduction will help policy makers and practitioners to design, allocate resources and implement BDS programmes effectively. For example, policy makers and practitioners could set up a training institute to train counsellors to improve their expertise in order to improve co-production. This study therefore investigates the concept of co-production in counselling in microfinance setting and formulates a conceptual framework that could be useful for practitioners, policy makers and researchers.

The remainder of the article is organized as follows. First we discuss the characteristics of the owner managers in microfinance setting. Second we discuss business counselling. Third we present concept of co-production. Fourth we discuss the development of conceptual framework and finally the discussion.

\section{Characteristics of the Owner Manager}

Prior to discussing business counselling and the role of counsellor, the unique characteristics of MSE Owner Managers (Owner manager is someone who manages a MSE, in this study owner manager is a client of MFI and an entrepreneur too) are explored. The understanding 
of these characteristics would be useful to counsellor so that they can act as better counsellors and tailor-make the counselling programmes. Owner Manager of a MSE enjoys independence and ownership in terms of finance and psyche (Ghobadian and O’Regan, 2006). The changes in income of the Owner Manager affect his monthly income and life style. The way the business develops is based on the Owner Manager's personal experiences in which earlier problems have been addressed (Krueger, 2007; Thorpe et al., 2006). Moreover, the Owner Manager takes a holistic view of management and is highly dependent on personal relationships and key stakeholders. Furthermore, the Owner Managers often prefer to learn through peers and by doing things, rather than through the formal sources such as training (Gibb, 2009). Given these characteristics of the Owner Manager, counsellors need to have a considerable degree of understanding of how these characteristics impact the management of a business.

\section{Counselling}

Counselling refers to the actual dissemination of knowledge and advice to the entrepreneurs in the domain of business especially star-ups and early stages of the business ventures (Chrisman et al., 1987; Nahavandi and Chesteen, 1988; Smeltzer et al., 1991). Counselling is different to that of consulting. Consulting is limited to providing of specific knowledge to solve a problem whereas counselling is a process which leads to future changes in the behavior (Boyd, 1993). The distinction can be explained by the proverb, "when you give man a fish, he eats for a day. When you teach man to fish, he eats for a life time”. The former explains the consulting and the latter explains the counselling (Boyd,1993). Further counselling guides and assists the clients/entrepreneurs to find out solutions to his/her situation. Counselling is based on relationships and often counsellors' services are sponsored (e.g. counsellors are employed by Microfinance Institutions to provide guidance and assistance to clients). The relationships between the counsellor and the client in counselling 
are not necessarily commercial in nature. However in some instances counsellors could charge fees beyond basic business assistance. In contrast, consulting is usually project driven, transactional and often client sees the problem (Evans and Volery, 2001; Boyd, 1993)

Counselling has been considered a pivotal element in business assistance programmes. Counselling in microfinance setting could be different to that of counselling provided at other business assistance programmes such as Small Business Development Centres, Small Business Institutes in developed world in terms of the context and location. Counsellors of MFI provide counselling to entrepreneurs (owner managers) in different forums and locations such as at MFI, at owner manager/entrepreneur group meetings and in the field. Counsellors attached to MFIs provide group counselling and one to one counselling to entrepreneurs (de Wildt and Ruijter, 2004; ADEMCOL, 2001). This study focuses on one to one counselling. The counsellors in MFI setting generally provide following Business Development Services through to owner managers : financial literacy knowledge, assistance in business plan preparation, assistance in business registration, knowledge in record keeping, linking to training, creating market linkages, creating loan linkages, formation of producer groups, technology transfer (Merten and Paul, 2007; de Wildt, and Ruijter, 2004; ADEMCOL, 2001; Gunathilaka,. 1997).

The counsellors of MFIs directly deal with the owner managers and provide necessary business assistance to help them improve their business ventures.

Counsellors provide proactive and reactive counselling to owner managers. Proactive counselling refers to where counsellors identify owner managers' problems and provide solutions. Reactive counselling refers to where the counsellors provide solutions to owner managers when they approach counsellors with problems relating to their business ventures 
(Rice, 2002). Further Boyd (1993) asserts that business counsellors provide three types of counselling: 1. Developmental counselling 2. Rational redirection 3. Crisis intervention

Developmental counselling is long term counselling. The goal of developmental counselling is to build a foundation of knowledge that will prepare clients for the business community and move them up the counselling hierarchy. This approach looks at the ongoing developmental needs of the client. Sometimes, client needs rational redirection in which client needs to be told that his/her idea is irrational. Crisis intervention is also part of counselling and crisis can often happen in a recession. Pre venture client may also face crises. In crisis intervention, counsellor helps client circumvent the crisis (Byod, 1993).

We believe that there should be collaboration between the counsellor and owner manager (i.e. co-production) to have a successful counselling intervention in microfinance setting.

Figure 1 below depicts how collaboration/co-production takes place in business counselling within the micro finance context.

\begin{tabular}{|c|c|c|}
\hline $\begin{array}{c}\text { Microfinance } \\
\text { Institution }\end{array}$ & Business Counselling & $\begin{array}{c}\text { Owner Manager/ } \\
\text { Client }\end{array}$ \\
Micro and Small \\
Enterprise (MSE)
\end{tabular}

Figure 1: co-production in business counselling

\section{Co-production}

We adopt the view of co-production as "join efforts between two parties who jointly determine their output of their collaboration (Parks et al., 1981) for this study. Further we consider the dyadic relationships between individuals in this study (i.e. dyadic relationship 
between the counsellor and the owner manager). The following explains the concept of coproduction.

\subsection{Concept of Co-Production}

The concept of co-production was originally developed by the workshop in Political Theory and Policy Analysis at Indiana University in 1973. Originally the concept of co-production related to the clients or citizens involvement in production (i.e. direct user involvement either in public or private sectors). This concept fuelled a great interest among public administration scholars in US on the 1970 and the 1980s (Parks et al., 1981).

Scholars argued that citizens as clients would receive an effective and efficient service from the professional staff employed by large bureaucratic agencies. After studying police services in US they did find out that centralized police department was unable to provide a better direct service to the clients /citizens (Ostrom, 1999). Hence they realized that not only the service provider but also the client need to collaborate in the production. Further they also realized that the production of service as opposed to a good was difficult without the active participation of those receiving the service (Ostrom, 1999).Thus the term of co-production focuses on the individuals and groups in the production of services at the micro levels but it could have an impact on both the meso and the macro levels of the society (Ostrom, 1999).

According to Parks et al. (1981) co-production involves joint efforts between two parties who jointly determine the output of their collaboration. Here two parties mean the consumer and the producer. In co-production, contrary to the passive role played by the consumer in the production, the efforts of the consumers are the central to the production of the output.

Parks et al. (1981) introduced the following equation to represent the interdependent coproduction. 
$\mathrm{Q}=\mathrm{CRP}^{\mathrm{d}} \mathrm{CP}{ }^{\mathrm{e}}$

where $\mathrm{Q}=$ output; $\mathrm{RP}=$ regular producer inputs; $\mathrm{CP}=$ consumer producer inputs; $\mathrm{c}=$ a scaling factor; and d and e are the respective output elasticities of each input.

The concept of co-production was initially studied in the context of industrial and service markets. Further co-production was originally discussed in terms of economic efficiency gained from collaborating with a customer in business to business context that resulted in competitive advantage (Fitzsimmons, 1985). In 1990s scholars started to discuss the use of co-production concept in consumer markets. In consumer markets, the emergence of 'customizing consumer' was witnessed who takes an active role in the production process (Firat, 1991; Firat and Venkatesh, 1993, 1995; Firat et al., 1995; Firat and Shultz, 1997). In recent times, the work of Prahaladand Ramaswamy (2000, 2002, 2004a, 2004b) and Vargo and Lusch $(2004,2006)$ on value co-creation and service dominant logic of marketing, new school of thought has driven the idea of co-production. Until recently the dominant thinking was that customer value creation goes with the product (Goods Dominant logic, G-D). However Vargo and Lush (2004) proposed the Service Dominant (S-D) Logic in which service provision rather than goods is the foundation of economic exchange. These authors argue that value does not exist only in the finished good but value is defined and created in co-production with the consumer (Vargo and Lusch, 2006). They propose that goods are part of distribution in the service provision and customer is always a co-producer. Moreover their S-D logic identifies how customer collaboration affects the co-production and how it brings about benefits such as lower costs, customized service offerings and increased productivity. Marketing theory encourages service providers and customers to interact and customers to participate in the service production process (Vargo and Lusch, 2004; Auh et al., 2007; Lusch et al., 2007). Etgar (2008) describes co-production as customers participating in the 
performance in the various activities in the production process and encompasses all cooperation formats between the customer and the service provider.

\subsection{Co-production as a dyadic relationship in Service literature}

Co-production is a vital construct in service literature (Zeithaml et al., 2006). The production phase of service cannot be disconnected from the consumption phase and customer always plays a vital role in service provision. (Lovelock and Wirtz, 2004) Customer participation is defined as "the degree to which the customer is involved in producing and delivering the service. (Dabholkar, 1990). In service co-production, both the customer contact employees and customers interact and participate in the production. (Meuter,and Bitner, 1998) Further according to Vargo et al (2008) the points of customer -firm interaction are critical for creating value and value is co-created through their reciprocal and mutually beneficial relationship. Similarly in service co-production is based on interactions between the firm and the customer at individual levels

Thus dyadic relationship between the customer contact employees and customers are important in co-production. There are few studies done on co-production considering the dyadic relationships. Rice (2002) investigates dyadic relationship between the incubator managers and entrepreneurs in his exploratory study on co-production of business assistance in business incubators. Further Guo and NG (2011) in their study on outcome based equipment services dyadic relationships are examined.

\subsection{Three factors that are needed for co-production of service}

Three customer factors are key to the effective co-production: Perceived clarity of the task/role ability or competence and motivation (Meuter et al. 2005; Bettencourt et al. 2002; 
Lengnick-Hall et al. 2000; Lengnick-Hall 1996; Lovelock and Young 1979). These three factors are used when describing the co-production factors identified in the study.

Task clarity refers to the extent which customers understand what is required of them in service The clearer a customer's role expectations, the greater is the likelihood that their contributions will lead to improved service outcomes (Mills et al. 1983). Rodie and Kleine (2000) mention four types of role clarity namely customer's own experience with a particular service provider, customer's experience with service provider's direct competitors, customer's experience with similar service contexts and the behaviour of other customers.

Customer ability refers to the quality of input customer provides to the service production process. Customer's useful and timely customer contributions enhance the co-production output (Schneider and Bowen, 1995).

According to Auh et al (2007) and Moorthy et al (1997) ability is defined as expertise and they believe that customer with experience (i.e. Expertise) in service is better equipped to make valuable contributions to the production of service and thus co-production. Rodie and Kleine (2000) provide a broad definition of ability which includes knowledge, skills and experience of the customer. Further customer self efficacy (i.e. perceived ability (belief) to perform a task) also can be discussed under customer ability (Bandura, 2001) and customer self efficacy improves the co-production (Ford and Dickson, 2012).

Rodie and Kleine (2000) mention three types of benefits that motivate customer participation namely efficiency in service process, efficiency of the service outcome and psychological benefits (e.g. Novelty, enjoyment and increased perceived control).

\section{Development of Conceptual framework}

In this study we attempt to establish a conceptual framework (figure 2) for counselling grounded on concept of co-production. 
Each of the elements in the conceptual framework is explained below.

\subsection{Contextual factors}

We believe that co-production between the counsellor and the owner manager would be influenced by certain contextual factors embedded in the microfinance setting. Two MFIs (i.e. two cases) based in Sri Lanka are introduced in this article to show the differences in contextual factors based on the MFI which have a bearing on co-production in counselling. The two cases are SEEDS and HNB. SEEDS is a guarantee company registered under the company act and was established in 1998. SEEDs provides both credit and BDS to micro entrepreneurs and it was active throughout Sri Lanka. SEEDS provides credit to the clients/members through mainly group lending methodology. HNB is a private well established bank in Sri Lanka. In 1989, HNB introduced Village awakening microfinance model in order to cater for micro enterprises. The salient feature of this programme is village awakening advisor (counsellor) who went to the village and provided banking services to the clients. HNB caters for all the districts in the country. Further HNB uses individual lending method to provide credit to clients.

This introduction to two cases will help reader understand this article and development of conceptual framework better. The following table compares and contrasts the contextual factors of two MFIs in Sri Lanka. 
Table 1: Contextual factors of MFIs

\begin{tabular}{|c|c|c|c|c|}
\hline \multirow[t]{2}{*}{ MFIs } & \multicolumn{4}{|c|}{ Contextual factors related to each MFI } \\
\hline & $\begin{array}{l}\text { BDS } \\
\text { organizational } \\
\text { structure }\end{array}$ & $\begin{array}{l}\text { Groups } \\
\text { (Lending } \\
\text { methodology) }\end{array}$ & $\begin{array}{l}\text { Awareness and } \\
\text { social } \\
\text { mobilisation } \\
\text { programmes }\end{array}$ & Client segments \\
\hline SEEDS & $\begin{array}{l}\text { Two } \\
\text { departments for } \\
\text { credit and BDS }\end{array}$ & Group & $\begin{array}{l}\text { Awareness } \\
\text { sessions and } \\
\text { social } \\
\text { mobilization } \\
\text { programmes }\end{array}$ & $\begin{array}{l}\text { Poor and non } \\
\text { poor clients }\end{array}$ \\
\hline HNB & $\begin{array}{l}\text { One department } \\
\text { for credit and } \\
\text { BDS }\end{array}$ & Individual & $\begin{array}{l}\text { Awareness } \\
\text { sessions }\end{array}$ & Non poor clients \\
\hline
\end{tabular}

These identified contextual factors are explained below.

\section{BDS organizational structure}

The literature shows that certain MFIs provide credit and BDS through the same department (e.g. HNB). Thus counsellors attached to these MFIs have to provide both credit and BDS (Merten and Paul, 2007; ADEMCOL, 2001) In contrast there are certain MFIs (e.g. SEEDS) in which credit and BDS are provided by two departments (i.e. credit and BDS). Thus counsellors attached to these MFIs (who are employed by BDS department) have to engage in only BDS thus they have more time for counselling compared to MFIs where counsellors 
have to provide both credit and BDS. Thus workload of the counsellor may vary depending on the BDS structure of MFI and this could possibly have a bearing on the co-production.

\section{Groups}

Micro finance literature shows that certain MFIs (e.g. SEEDS) lend money to owner managers (members) in a group (i.e. group lending: The basic idea of group lending is that loans are given to the individual members of the group but group is responsible for the repayment of the loans of the individual members to the MFI) or lend money to individual owner managers (i.e. individual lending: Individual lending demands collateral and there are no groups of clients formed). (Denotes and Alexandar, 2004; Khavul, 2010).

MFIs that use group lending form groups of clients. Each group consists of 3-10 clients/members. Members in the group hold group meetings and these group meetings are attended by the counsellors of MFIs to provide BDS. Thus owner managers obtain counselling at group meetings often. Counsellors working for MFIs having groups of owner managers find it easy to provide counselling as members (owner managers) come to meetings regularly. In contrast counsellors working for MFIs using individual lending (e.g. HNB) need to visit owner managers individually as owner managers do not meet each other as a group. Thus we believe that these groups could influence the counselling experience between the counsellor and owner manager and hence could affect co-production.

\section{Awareness and social mobilisation programme}

MFIs provide Awareness and social mobilization programmes prior to providing micro credit and BDS. Awareness and social mobilization programmes involves awareness building on micro credit and BDS, and formation of self-help groups (Tilakaratne et al, 2005). Through this programme clients become familiar with counselling hence we believe that awareness 
and social mobilization programmes could enhance owner managers' ability and motivation to attend counselling and thus may improve the incidence of co-production.

\section{Client Segments}

MFIs cater for both poor and non poor client segments. The literature shows that MFIs often cater for non poor clients as poor clients are not receptive to BDS (Judith, 2004; Gunathilaka, 1997). The extant literature (Judith, 2004; Gunathilaka, 1997) assert that poor clients are generally risk averse, less resourceful and less skilful to start a micro enterprise and manage and hence BDS may not for them and thus counselling may not work for this group. Thus counselling may be appropriate for non poor clients and client segment may have a bearing on co-production in counselling.

\subsection{Co-production factors in counselling}

There are number of antecedent factors relating to counsellors and owner managers in order to have successful counselling intervention. For example counsellor's knowledge and owner manager's willingness. Hence, we propose following co-production factors relating to counselling based on the extant literature.

\section{Expertise of counsellor}

The extant literature shows that that counsellor's expertise enhances the co-production of couselling. Expertise of the counsellor refers to the business knowledge and the experience of counsellor. Rice (2002) in his study on business incubators asserts that business knowledge and experience of the incubator managers influence the co-production with the entrepreneurs. Chirsman (1989) emphasizes the importance of qualifications and experience of consultants in delivering business services to small and medium entrepreneurs in his study based on small business development centres in the US. Similarly we assume that counsellors attached to 
MFIs expertise enhanced the co-production. Thus counsellors with higher expertise (e.g. degree in business management and experience with working with owner managers) could help owner managers improve their business ventures and thereby improve the co-production.

\section{Counsellor-owner manager communication}

The extant literature on services shows that communication between the service provider and the client are important in co-production (Auh et al, 2007; Bettencourt et al, 2002). Auh et al (2007) define communication as formal and informal sharing of meaningful and timely information between the client and the service provider. Further Betterncourt et al (2002) highlight the importance of communication openness in co-production. According to Bettencourt et al (2002) communication openness is open and honest client communication of all information that is pertinent to the project. Further these authors highlight the importance of communication between the client and the service provider for partners' satisfaction, channel coordination and effective partnerships. When there is an effective communication then the service providers and clients tend to share potentially sensitive information leading to increased co-production. Further communication improves the relationship between parties and builds trust by resolving client's queries and managing expectations (Sharma and Patterson, 1999). Further Communication between the service employees and the customer would enhance the clarity of the task of the customer (Auh et al, 2007). Thus we propose the communication between the counsellor and owner manager improves the incidence of co-production.

\section{Counsellor readiness}

Rice (2002)'s study on co-production in incubator context identifies the time available for incubator manager to engage in co-production activities as opposed to non co-production activities which he calls readiness has a bearing on the co-production between the incubator 
manager and the entrepreneur. Further the studies done by Douglas and Eileen (2011) and Chrisman and Mcmullan (2004) find that advisors of business advisory services spending number of hours with the clients improve the business performance. Similarly we propose that counsellors attached to MFIs readiness in terms of having time available for counselling has a correlation with co-production in counselling.

\section{Owner manager willingness}

The literature shows that clients should be willing to take part in co-production. The findings of Rice (2002)'s study on business incubators indicates that entrepreneurs should be willingness to co-produce with incubator managers. According to Lengnick-Hall et al. (2000) in addition to being able to contribute, customers must be willing to get involved in coproduction. Schayek and Dvir (2009) 's study on public assistance programmes on small business performance find small business owner's willingness is vital to obtain coaching. Moreover Etgar (2007) assert that consumers' willingness is the key to engage in coproduction and willingness is influenced by certain antecedent factors such as macro environmental conditions, consumer linked, product linked and situational linked factors. Similarly we believe that owner manager willingness to engage with the counsellor is vital in co-production in counselling.

\section{Interpersonal Relationship}

Guo and NG (2010) stress the importance of the client's relationship with the service provider in service production and delivery. Moreover Bettencourt et al (2002) too highlight the importance of relationship between the client and the service provider in co-production. Further Guren et al. (2000) assert that customers having long term relationships with service providers become effective co- producers. Thus we propose that interpersonal relationship between the counsellor and owner manager has a positive correlation with the co-production. 


\subsection{Co-Production outcomes}

Co-production outcomes could vary depending on the setting (e.g. incubator, health, solid waste collection). Further co-production outcomes may also change in terms of the coproduction partners' point of view and those who measure the aggregate socio economic impact. For example in business incubator setting, co-production outcome for the coproduction partners (i.e. Entrepreneurs and incubator managers) would be business assistance. However the sponsors and management of business incubator are more concerned with aggregate socio economic impact co-production outcomes such as job creation (Rice, 2002, Schroefer, 1990). Similar patterns could be observed in other examples of coproduction such as anti crime, solid waste collection, health service, education programmes, finance industry etc.

Similarly, in microfinance setting there could be two types of co-production outcomes:

1. Sponsors and management of MFI related outcomes (i.e. aggregate socio economic impact)

2. Co-production partners related outcomes

Each of these is explained below.

Sponsors and management of MFIs related outcomes: Schroeder, (1990) indentifies job creation, neighbourhood revitalization, technology transfer, improvement in the economic condition of disadvantaged minorities, and so forth as sponsors and management related coproduction outcomes for business incubators. Similarly we propose by providing BDS through counselling sponsors and management of MFIs would like to achieve certain objectives which have an aggregate socio economic impact. These objectives would be number of new businesses generated, number of new employments generated, development of the management of micro enterprises. 
Co-production partners related outcomes: MFIs and owner managers are the partners of co-production. Thus partners' outcomes could be twofold: 1. MFI related outcomes 2. Owner manager related outcomes (ADEMCOL, 2001; De Wildt and Ruijter, 2004; Karalan and Valdvia, 2006)

MFIs related outcomes are better loan repayments, better client retention and better customer satisfaction. The studies show that clients who obtain BDS tend to repay the loans taken from MFIs. Further clients who have obtained BDS tend to stay with the MFIs obtaining more loans and BDS (i.e. client retention) Moreover clients' satisfaction would be high with the BDS obtained (Henry 2006; de Wildt, and Ruijter,2004; Halder, 2003; ADEMCOL, 2001).

Owner manager related outcomes would be better sales and profits in their micro enterprises and better business knowledge. Owner managers could develop their businesses as a result of BDS obtained through counselling which would result in better sales, profits and business knowledge (de Wildt, and Ruijter, 2004; Halder ,2003; ADEMCOL, 2001).

Based on the information provided thus far, the following conceptual framework (figure 2) has been proposed for co-production in business counselling.

\begin{tabular}{|l|l|l|}
\hline \multicolumn{2}{|l|}{ Contextual factors: } & \multicolumn{1}{|c|}{ BDS Organizational structure } \\
manager co-production \\
factors
\end{tabular}


Figure 2: Conceptual framework

Theoretical statements derived from the model provide a basis for investigative work on BDS in microfinance setting. The model is based on the following theoretical propositions:

1. The expertise of the counsellors help improve the performance of the owner managers' and hence increase the incidence of co-production between the counsellors and the owner managers

2. The higher readiness of the counsellors improve the business performance of owner managers and hence increase the co-production between the counsellors and the owner managers

3. The improved communication between the counsellors and the owner managers lead to increased information sharing between parties, improved interpersonal relationships and improved clarity of task resulting in increased co-production

4. The interpersonal relationship between the counsellors and the owner managers would improve the performance of both MFIs and the MSEs and hence improve coproduction

5. The willingness of the owner managers to co-produce with the counsellors improves the co-production

6. Contextual factors such as BDS organizational structure, client groups, client segments and awareness and social mobilisation programmes influence the coproduction between the counsellors and the owner managers 
7. Co-production in counselling influenced by the counsellor-owner manager related factors (e.g. expertise, willingness) and contextual factors (e.g. groups) would result in co-production outcomes: donor and management related outcomes and partners' related outcomes.

\section{Discussion}

The paper discusses the importance of co-production in business counselling within the microfinance setting. There is a dearth of academic literature on business counselling. Further none of the studies have used the concept of co-production to examine business counselling in a microfinance setting. Hence the aim of this paper is to introduce a conceptual model based on the concept of co-production to examine business counselling. In the proposed model, co-production factors and co-production outcomes relevant to the coproduction in counselling have been identified. The study suggests that counsellor expertise, counsellor readiness, counsellor - owner manager communication, counsellor - owner manager relationship and owner manager willingness are the co-production factors in counselling. Thus MFIs should focus on these factors in order to improve co-production. For example, MFIs could improve the expertise of the counsellors by recruiting counsellors with higher educational qualifications (e.g. degrees) and experience and giving them continuous training. Further MFIs can get together and set up a training institution to train counsellors so that counsellors' expertise can be enhanced. Further MFIs should allow counsellors to spend much time with the owner managers by designing their jobs so that their readiness would be increased. Moreover the counsellors should be educated the importance of communication (e.g. counsellors should use non technical language with owner managers) so that they can communicate with the owner managers effectively to improve co-production. Moreover the counsellors should be encouraged to maintain better relationships with the owner managers. This can be done by counsellors' contacting owner managers frequently and maintaining 
social interactions with the owner managers. Since willingness of the owner managers in key for successful co-production, MFIs should focus on certain antecedent factors such as location, timing of counselling so that willingness of owner managers could be enhanced. The resulting outcomes of co-production are of two kinds: Donors and management of MFIs specific and Partners specific. Donors and management of MFIs specific outcomes include number of MSEs created, number of employments created and improvement of management of MSEs. Partner specific outcomes are twofold: MFI specific and owner manager specific. MFI specific outcomes identified are better loan repayments, better client retention and client satisfaction. Owner manager specific outcomes are improved profits, sales and improved business knowledge. In addition to this, the study also identified some contextual factors that could influence the co-production in business counselling such as BDS structure, groups, client segments and awareness and social mobilisation programmes. MFIs may need to pay attention to these factors as well in order to improve co-production. For example, MFIs having BDS structure which demands counsellors to work both credit and BDS disciplines must facilitate them to spend more time with owner managers (i.e. readiness) in BDS counseling by designing their jobs. Further counsellors working for MFIs not having client groups (e.g. HNB) need to visit owner managers often in order to co-produce effectively as they do not have group meetings as MFIs having group structure to meet clients on regular basis. Thus management of MFIs not having client groups must make sure that their counsellors visit owner managers on regular basis to improve co-production. Since awareness and social mobilisation programmes improve owner managers' ability and motivation to engage in co-production, MFIs must pay attention to provide such programmes to potential owner managers who wish to join MFIs to increase co-production. The right clientele is important for effective co-production. The literature ( Shaw, 2004) shows that credit and BDS do not work for poorer clients as poorer clients are more interested in satisfying their 
basic needs ( e.g. foods, housing) rather than engaging in counselling. Thus when investing on BDS, MFIs need to cater for right clientele (i.e. not poor clients) in order to reap the benefits of co-production. However, the governments can collaborate with MFIs to provide BDS to poor clients by satisfying the basic needs of poor clients so that poor clients could coproduce with MFIs. .

Microfinance literature (Attapattu, 2009; Goldmark,1999) reveals that MFIs find it difficult to finance BDS programmes due to lack of funding coming from donors. Thus promoting coproduction in counselling, MFIs can obtain better loan repayments (i.e. co-production outcome), which in turn help the sustainability of BDS programmes. Moreover the governments and donors can provide funding for MFIs to provide BDS so that co-production in counselling could be sustained. The governments and donors must consider providing funds for BDS as a long term investment as BDS provides numerous benefits to MFIs, owner managers and stakeholders.

The framework developed in this study and the resultant propositions provide a starting point for empirical research about co-production in business counselling within the microfinance setting and can be used for the development of a testable hypothesis. Furthermore, the model could aid microfinance policymakers as it provides a basis for formulating strategies based on co-production.

Though in this paper, the concept of co-production has applied to microfinance, this concept can be applied to different industries and contexts. Moreover this paper focuses on coproduction between the service provider and the client (i.e. collaborative co-production) (Humphreys, 2008). However there could be a co-production between clients (i.e. collective co-production)( Humphreys, 2008) . For example owner managers in a group formed by a MFI could co-produce BDS (e.g. experienced owner manager provide counselling to another 
in- experienced owner manager in a group). Similarly in other industries and contexts not only collaborative co-production but also collective co-production can take place. Thus future researches can focus on both collaborative and collective co-production in different industries and contexts.

\section{References}

ADEMCOL (2001). Bundling Microfinance and Business Development Services (BDS):A Case Study from ADEMCOL in Colombia. Asociación para el Desarrollo Microempresarial Colombiano (ADEMCOL) and Women's Opportunity Fund, Micro enterprises best practices, US Aid project.

Auh, S., Bell, S.J., McLeod, C. S., and Shih, E. (2007). Co-production and customer loyalty in financial services, Journal of Retailing, 83: 359-370.

Attapattu, A.,( 2009). State of microfinance in Sri Lanka. Colombo: Institute of Microfinance.

Bandura, A. (2001). Social cognitive theory: An agentic perspective. Annual Review of Psychology, 52: 1-26.

Bettencourt, L., Ostrom, A., Brown, S., and Roundtree, R. (2002).Client co-production in knowledge-intensive business services, California Management Review, 44: 100-128.

Boyd, J. A. and Wisconsin Univ, M. U. E. (1993). A Business Advisor's Guide to Counselling Theories. Business School Press.

Chrisman, J. J. (1989). Strategic, administrative, and operating assistance: The value of outside consulting to pre-venture entrepreneur', Journal of Business Venturing, 4: 401418.

Chrisman, J. J., and Mcmullan, W. E., (2004). Outsider assistance as a knowledge resource for new venture survival. Journal of Small Business Management, 42: 229-244. 
Chrisman, J.J., Nelson, R.R., Hoy, F., Robinson, R.B. (1985). The impact of SBDC consulting activities. Journal of Small Business Management, 23: 1-11.

Dabholkar, P. (1990). How to improve perceived service quality by improving customer participation. In B. J. Dunlap (ed) Developments in Marketing Science, Academy of Marketing Science, Cullowhee.

De Wildt, and Ruijter, M. d. (2004). Linking Business Development Services to Financial services: The case of Financiera Solución in Peru. funded by ILO.

Denotes, V., and Alexander, S. K. (2004). The individual micro-lending contract: is it a better design than joint-liability? Evidence from Georgia. Economic Systems, 28: 155-176. doi: 10.1016/j.ecosys.2004.03.006

Douglas, J. C., and Eileen, F. (2011). Publicly funded business advisory services and entrepreneurial outcomes. Research Policy. doi: 10.1016/j.respol.2011.09.004 ed.). Pearson/Prentice Hall, Upper Saddle River.

Etgar, M., (2007). A descriptive model of the consumer co-production process. Journal of the Academy of Marketing Science, 36: 97-108.

Evans, D. and Volery, T. ( 2001). Online business development services for entrepreneurs: an exploratory study. Entrepreneurship and regional development. 13 (2001) , 333 - 350

Firat A., and Shultz, C. J. (1997).'From segmentation to fragmentation, European Journal of Marketing, 31: 183-208.

Firat, A. (1991). The consumer in post modernity', Advances in Consumer Research. 18: 7076.

Firat, A., and Venkatesh, A. (1993). Post modernity: the age of marketing. International Journal of Research in Marketing, 10: 227-249.

Firat, A., and Venkatesh, A. (1995). Liberatory postmodernism and the re-enchantment of consumption, Journal of Consumer Research, Vol 22, No 3, pp 239-267. 
Firat, A., Dholakia, N., and Venkatesh, A. (1995). Marketing in post modern world, European Journal of Marketing, 29: 40-56.

Fitzsimmons, J.A. (1985). Consumer participation and productivity in service operations. Interfaces, 15: 60-67.AnnArbor, MI: University of Michigan Press.

Ford, R. C. and Dickson, D. R. (2012). Enhancing customer self-efficacy in co-producing service experiences. Business Horizons, 55: 179-188. doi: 10.1016/j.bushor.2011.11.005.

Ghobadian, A., and O’Regan, N. (2006). The impact of ownership on small firm behaviour and performance, International Small Business Journal 24: 555-86.

Gibb, A. (2009). Meeting the development needs of owner managed small enterprise: A discussion of the centrality of action learning. Action Learning: Research and Practice, 6: 209-227.

Gruen, T. W., Summers, J. O. and Acito, F. (2000). 'Relationship marketing activities, commitment, and membership behaviours in professional associations', Journal of Marketing, 64: 34-49.

Gulli, H., and Berger, M., (1999). Microfinance and poverty reduction - evidence from Latin America. Small Enterprise Development, 10: 16-28.

Gunathilaka, R. (1997). Credit-Based participatory Micro Enterprise Development ,Poverty Alleviation Strategies in Sri Lanka: What have we learned? Institute of Policy Studies.

Goldmark, L., (1999). The financial viability of business development services. Small enterprise development, 10 (2), 4-16.

Guo, L., and Ng, I. (2011). The co-production of equipment-based services: An interpersonal approach. European Management Journal, 29: 43-50. doi: 10.1016/j.emj.2010.08.005.

Halder, S. R., (2003). BRAC's business development services - do they pay. Small Enterprise development, 14: 10.

Henry, S., (2006). Business development services: How do we enhance entrepreneurial skills 
in MFI clients. Microcredit Summit.

Hulme, D., and Mosley, P., (1996). Finance against poverty. London: Routledge.

Humphreys, A.,(2008). Understanding Collaboration and Collective Production: New Insights on Consumer Co-Production. Advances in consumer research, 35, 63-66.

Johnson, S., and Rogaly, B., (1997). Microfinance and poverty reduction. . Oxford: Oxfam.

Judith, S. (2004). Microenterprise Occupation and Poverty Reduction in Microfinance

Programs: Evidence from Sri Lanka. World Development, 32: 1247-1264. doi:

10.1016/j.worlddev.2004.01.009

Karlan, D., and Valdivia, M., (2006). Teaching entrepreneurship: Impact of business training on micro finance clients and institutions. Economic Growth Centre Discussion Paper, No, 941, Yale University.

Khavul, S. (2010). Microfinance: Creating opportunities for the poor? Academy of Management Perspectives, 24: 58-72.

Krueger, N. (2007), 'What lies beneath? The experiential essence of entrepreneurial thinking', Entrepreneurship Theory and Practice, 31: 123-38.

Lengnick-Hall, C. A., Claycomb, V., and Inks, L. W. (2000). From recipient to contributor: Examining customer roles and experienced outcomes, European Journal of Marketing, Vol 34, No 3/4, pp 359-383.

Lengnick-Hall, C.A. (1996). Customer Contributions to Quality: A Different View of the Customer-Oriented Firm, Academy of Management Review, 21: 791-824.

Littlefield, E., Morduch, J., and Hashemi, S., (2003).. Is microfinance an effective strategy to reach the millennium development goals? CGAP focus note 24 . < www.Cgap.Org>

LMPA. (2012). Microfinance review -Sri Lanka, performance and analysis report-2011

Lovelock, C. H. and Wirtz, J. (2004.) Services Marketing: People, Technology, Strategy. (5th ed.). Pearson/Prentice Hall, Upper Saddle River. 
Lovelock, C.H. and R.F. Young (1979). Look to Consumers to Increase Productivity. Harvard Business Review, 57 (May/June) 168- 176.

Lusch, R. F., Vargo, S. L., \& O'Brien, M. (2007). Competing through service: Insights from service-dominant logic. Journal of Retailing, 83: 5-18.

Mead, D. D. and Lieadholm, C. (1998). The dynamics of micro and small enterprises in developing countries. World Development, 24: 481-487.

Merten, S., and Paul, V. (2007). Synergies through linkages: Who benefits from linking micro-finance and business development services? World Development, 35: 1341-1358.

Meuter, M. L. and Bitner, M. J. (1998). Self-service technologies: Extending service frameworks and identifying issues for research. In D. Grewal and C. Pechmann (eds) AMA Winter Educators- Conference, American Marketing Association, Chicago.

Meuter, M. L., Bitner, M. J. , Ostrom, A. L. and. Brown, S. W. (2005). Choosing among alternative service delivery Modes: an investigation of customer trial of self-service technologies, Journal of Marketing, 69: 61.

Mills, P.K., R.B. Chase and N. Margulies (1983). Motivating the Client/Employee System as a Service Production Strategy, Academy of Management Review, 8: 301-310.

Moorthy, S., Ratchford B. T. and Talukdar, D. (1997). Consumer Information Search Revisited: Theory and Empirical Analysis, Journal of Consumer Research, 23: 263-277.

Mosley, P., and Hulme, D.(1998). Microenterprise finance: Is there a conflict between growth and poverty alleviation? World Development (Oxford), 26: 783-790.

Nahavandi, A., Chesteen, S.,(1988). The impact of consulting on small business: a further examination. Entrepreneurship Theory and Practice 13: 29-40.

Ostrom, E. (1999) 'Crossing the Great Divide: Coproduction, Synergy, and Development’ in M. McGinnis (ed.)

Prahalad C.K., and Ramaswamy, V. (2004b). The Future of Competition: Co-creating Unique Value with Customers, Harvard Business School: Boston, USA. 
Prahalad, C.K., and Ramaswamy V. (2002). The co-creation connection, Strategy and Business 27: 51-60.

Prahalad, C.K., and Ramaswamy, V. (2000), Co-opting customer competence, Harvard Business Review, 78: 79-87.

Prahalad, C.K., and Ramaswamy, V. (2004a). Co-creation experiences: the next practice in value creation. Journal of Interactive Marketing, 18: 5-14.

Rice, M. P. (2002). Co-production of business assistance in business incubators - an exploratory study, Journal of Business Venturing, 17: 163-187.

Rodie, A.R. and Kleine, S.S. (2000), Customer participation in service production and delivery” in T. A. Swatz, and D. Lacobucci. (eds), Handbook of Service Marketing and Management, 111-25, Sage, California.

Rogaly, B., (1996). Micro-finance evangelism, 'destitute women', and the hard selling of a new anti-poverty formula. Development in Practice, 6: 100-112.

Rogerson, C. M. (2001). In search of the African miracle: Debates on successful small enterprise development in Africa. Habitat International, 25, 115-142.

SAARC S. R., (2000). Micro enterprise development for youth. workshop Report, SAARC

Schayek, K., and Dvir, D. (2009). Measuring the effect of public assistance programs on small businesses' performance. Journal of General Management, 35: 3-20.

Schneider, B. and D.E. Bowen (1995). Winning the Service Game, Boston, MA: Harvard Business School Press.

Schroeder, S.D., (1990). The state of the business incubation industry, The National Business Incubation Association, Athens, $\mathrm{OH}$.

Shaw, J., (2004). Microenterprise occupation and poverty reduction in microfinance programs: evidence from Sri Lanka. World development, 32 (7), 1247-1264

Sharma, N. and P.G. Patterson (1999). The Impact of Communication Effectiveness and Service Quality on Relationship Commitment in Consumer, Professional Services. Journal of Services Marketing, 13: 151-170. 
Smeltzer, L.R., Van Hook, B.L., Hutt, R.W., (1991). Analysis of the use of advisers as information sources in venture startups. J Small Bus Manage 29 (3), 10-20.

Thorpe, R., J. Gold, R., Holt, R., and Clarke, J. (2006), Immaturity: The constraining of entrepreneurship, International Small Business Journal, 24: 232-50.

Tilakaratne, G., Wickramsinghe, U., \& Thusitha, K. (2005). Micro Finance in Sri Lanka : A Household Level Analysis of Outreach and Impact on Poverty (pp. 57). Sri Lanka: Institute of Police Studies of Sri Lanka.

Tybout, J. R. (2000). Manufacturing firms in developing countries: How well do they do, and why? Journal of Economic Literature, 38: 11-44.

Vargo S. L., and Lusch R.F. (2004). Evolving to a new dominant logic for marketing. Journal of Marketing, 68: 1-17.

Vargo S. L., and Lusch R.F. (2006). Evolving to a new dominant logic for marketing, In R. F. Lusch, and S. L. Vargo (eds), The Service Dominant Logic of Marketing, M.E. Sharpe, New York.

Vargo, S. L., Maglio, P. P. and Akaka, M. A. (2008). On value and value co-creation: A service systems and service logic perspective. European Management Journal, 26: 145152.

Wright, G. A., (1999). Examining the impact of microfinance services-increasing income or reducing poverty? Small Enterprise Development,, 10 (1), 38-47.

Zeithaml, V. A., Bitner, M. J. and Gremler, D. D. (2006). Services Marketing: Integrating Customer Focus Across the Firm. (4 ${ }^{\text {th }}$ ed.). McGraw-Hill. 